\title{
N-Terminal Regions of Prion Protein: Functions and Roles in Prion Diseases
}

\author{
Hideyuki Hara and Suehiro Sakaguchi * \\ Division of Molecular Neurobiology, The Institute for Enzyme Research (KOSOKEN), Tokushima University, \\ 3-18-15 Kuramoto, Tokushima 770-8503, Japan; hara@tokushima-u.ac.jp \\ * Correspondence: sakaguchi@tokushima-u.ac.jp; Tel.: + 81-88-633-7438
}

Received: 15 August 2020; Accepted: 27 August 2020; Published: 28 August 2020

\begin{abstract}
The normal cellular isoform of prion protein, designated $\operatorname{PrP}^{\mathrm{C}}$, is constitutively converted to the abnormally folded, amyloidogenic isoform, $\mathrm{PrP}^{\mathrm{Sc}}$, in prion diseases, which include Creutzfeldt-Jakob disease in humans and scrapie and bovine spongiform encephalopathy in animals. $\mathrm{PrP}^{\mathrm{C}}$ is a membrane glycoprotein consisting of the non-structural $\mathrm{N}$-terminal domain and the globular C-terminal domain. During conversion of $\mathrm{PrP}^{\mathrm{C}}$ to $\mathrm{PrP}^{\mathrm{Sc}}$, its 2/3 C-terminal region undergoes marked structural changes, forming a protease-resistant structure. In contrast, the $\mathrm{N}$-terminal region remains protease-sensitive in $\mathrm{PrP}^{\mathrm{Sc}}$. Reverse genetic studies using reconstituted $\mathrm{PrP}^{\mathrm{C}}$-knockout mice with various mutant $\mathrm{PrP}$ molecules have revealed that the $\mathrm{N}$-terminal domain has an important role in the normal function of $\mathrm{PrP}^{\mathrm{C}}$ and the conversion of $\mathrm{PrP}^{\mathrm{C}}$ to $\mathrm{PrP}^{\mathrm{Sc}}$. The $\mathrm{N}$-terminal domain includes various characteristic regions, such as the positively charged residue-rich polybasic region, the octapeptide repeat $(\mathrm{OR})$ region consisting of five repeats of an octapeptide sequence, and the post-OR region with another positively charged residue-rich polybasic region followed by a stretch of hydrophobic residues. We discuss the normal functions of $\operatorname{PrP}^{\mathrm{C}}$, the conversion of $\operatorname{PrP}^{\mathrm{C}}$ to $\operatorname{PrP}^{\mathrm{Sc}}$, and the neurotoxicity of $\mathrm{PrP}^{\mathrm{Sc}}$ by focusing on the roles of the $\mathrm{N}$-terminal regions in these topics.
\end{abstract}

Keywords: prion protein; prion; prion disease; neurodegeneration; protein conformation

\section{Introduction}

Conformational conversion of the normal cellular isoform of prion protein, designated $\mathrm{PrP}^{\mathrm{C}}$, to the abnormally folded, amyloidogenic isoform, $\mathrm{PrP}^{\mathrm{Sc}}$, is a key pathogenic event in prion diseases, a group of fatal neurodegenerative disorders that include Creutzfeldt-Jakob disease (CJD) in humans, scrapie in sheep, bovine spongiform encephalopathy (BSE) in cattle, and chronic wasting disease in deer [1-4]. These diseases are pathologically characterized by neuronal cell loss, spongiform degeneration, gliosis, and $\mathrm{PrPSc}^{\mathrm{Sc}}$ accumulation in the brain [5]. Prions, or proteinaceous infectious particles, are the causative agents of these diseases [6,7]. It is believed that prions consist of, if not entirely, $\mathrm{PrP}^{\mathrm{Sc}}$ molecules, and catalyze conformational conversion of $\mathrm{PrP}^{\mathrm{C}}$ to $\mathrm{PrP}^{\mathrm{Sc}}$ through a seeded protein polymerization mechanism, eventually propagating $\mathrm{PrP}^{\mathrm{Sc}}$ or prions themselves [6,7]. Indeed, it has been shown that mice devoid of $\mathrm{PrP}^{\mathrm{C}}\left(\mathrm{Prnp}^{0 / 0}\right)$ are resistant to prion infection, neither propagating prions nor $\mathrm{PrP}^{\mathrm{Sc}}$ in their brains nor developing disease even after intracerebral inoculation with prions [8-11].

$\mathrm{PrP}^{\mathrm{C}}$ is a highly conserved, glycosylphosphatidylinositol (GPI)-anchored membrane glycoprotein among mammalian species [12]. It is expressed most abundantly in the central nervous system, particularly by neurons, and to a lesser extent in other non-neuronal tissues, such as the lymphoreticular system, lung, and kidney [13]. $\mathrm{PrP}^{\mathrm{C}}$ consists of two domains; the highly flexible, nonstructural $\mathrm{N}$-terminal (residues 23-120) and the globular C-terminal (residues 121-231) [14-16] (Figure 1A). The globular C-terminal domain is composed of three $\alpha$-helices and two short anti-parallel $\beta$-sheets. Upon conversion to $\mathrm{PrP}^{\mathrm{Sc}}$, $\mathrm{PrP}^{\mathrm{C}}$ undergoes marked structural changes in its 2/3 C-terminal region to 
form a proteinase $\mathrm{K}(\mathrm{PK})$-resistant structure, while most regions of the $\mathrm{N}$-terminal domain remain PK-sensitive [13]. Reverse genetic studies using reconstituted $\mathrm{Prnp} \mathrm{p}^{0 / 0}$ mice and various mutant $\operatorname{PrP}$ molecules have revealed that the $\mathrm{N}$-terminal domain has an important role not only in the normal function of $\mathrm{PrP}^{\mathrm{C}}$ but also in the conversion of $\mathrm{PrP}^{\mathrm{C}}$ to $\mathrm{PrP}^{\mathrm{Sc}}$. The $\mathrm{N}$-terminal domain includes several characteristic regions, such as the so-called polybasic region (residues 23-31), which is rich in positively charged residues, the octapeptide repeat (OR) region (residues 51-90) consisting of five repeats of an octapeptide sequence, and the post-OR region (residues 91-120) including the second polybasic region followed by a stretch of hydrophobic amino acid residues [1-4] (Figure 1A). Here we discuss the role of each $\mathrm{N}$-terminal region in the normal function of $\operatorname{PrP}^{\mathrm{C}}$, the conversion of $\operatorname{PrP}^{\mathrm{C}}$ to $\operatorname{PrP}^{\mathrm{SC}}$, and the neurotoxicity of $\mathrm{PrP}^{\mathrm{Sc}}$.

\section{The N-Terminal Domain in the Function of $\operatorname{PrP}^{C}$}

\subsection{Biosynthesis of $\operatorname{PrPC}$}

The gene for PrPC, termed Prnp, in human and mouse consists of 2 and 3 exons and resides on chromosome 20 and 2, respectively. The protein coding sequence lies within the last single exon $[17,18]$. $\mathrm{PrPC}^{\mathrm{C}}$ is synthesized as a precursor protein in the endoplasmic reticulum (ER). The N-terminal and C-terminal sequences, which are rich in hydrophobic residues, are removed as a signal peptide sequence and a GPI-anchor signal sequence, respectively, in the ER (Figure 1A) [17,18]. $\operatorname{PrP}^{\mathrm{C}}$ also undergoes several post-translational modifications en route to the cell surface, including a GPI anchor attachment at the C-terminus, $\mathrm{N}$-glycosylation at two sites, and formation of a disulfide bond in the C-terminal domain (Figure 1A) [19-24]. On the cell surface, $\operatorname{PrP}^{\mathrm{C}}$ is predominantly localized at the so-called "raft" domains and constitutively internalized via clathrin- and caveolae-dependent endocytosis (Figure 1B) [25-27]. Some of the internalized $\operatorname{PrP}^{\mathrm{C}}$ molecules are recycled to the cell surface and others are trafficked to lysosomes for degradation (Figure 1B) $[28,29]$.
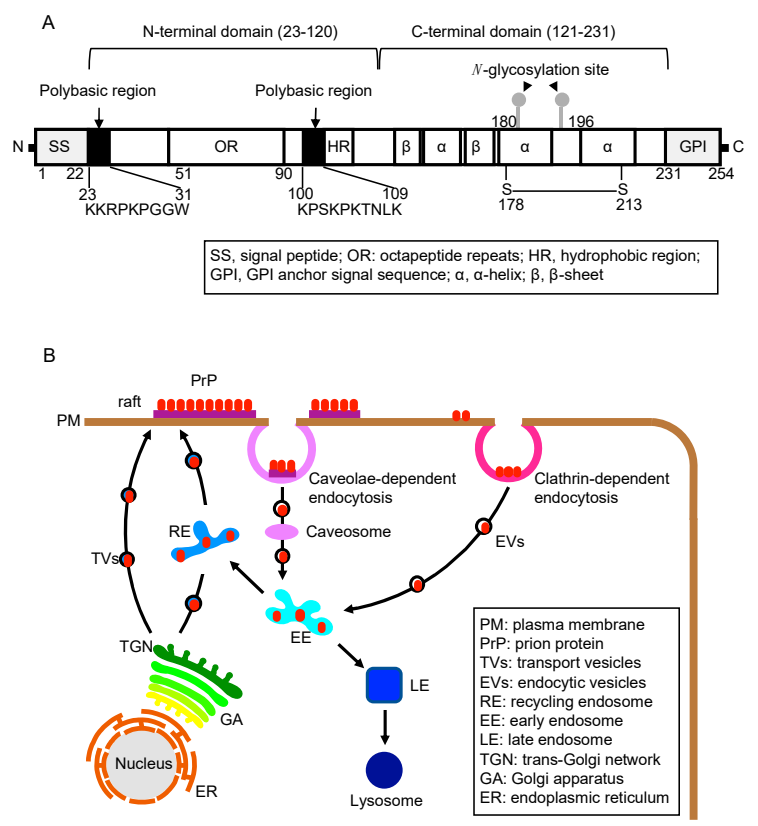

Figure 1. Structure and biosynthesis of $\mathrm{PrP}^{\mathrm{C}}$. (A) Structural configuration of $\mathrm{PrP}^{\mathrm{C}}$. Arabic numbers indicate positions of amino acids. (B) Biosynthetic pathways of $\mathrm{PrP}^{\mathrm{C}}$, including the vesicle transport pathway from the ER to the plasma membrane, particularly raft domains, and the clathrin- or caveolae-dependent endocytic pathway, which connects to recycling pathway or degradation pathway to lysosomes. 
Copper is known to bind to the OR region and induce the clathrin-dependent internalization of $\operatorname{PrP}^{\mathrm{C}}$ [30]. It has been suggested that copper binding could cause conformational changes in the $\mathrm{OR}$ region and thereby dissociate $\mathrm{PrP}^{\mathrm{C}}$ from conjectural molecules located at raft domains, and that dissociated $\mathrm{PrP}^{\mathrm{C}}$ then moves to non-raft domains, where it interacts with other conjectural non-raft molecules through the N-terminal polybasic region to be endocytosed via clathrin-coated vesicles [30]. We have shown that sortilin, a type 1 glycoprotein in the vacuolar protein sorting 10 protein family, interacts with the $\mathrm{N}$-terminal domain of $\mathrm{PrP}^{\mathrm{C}}$ and functions as a sorting receptor for lysosomal degradation of $\mathrm{PrP}^{\mathrm{C}}$ [31]. Sortilin also interacts with $\mathrm{PrP}^{\mathrm{Sc}}$ and facilitates its lysosomal degradation [31]. We also have shown that sortilin-knockout mice develop prion disease with shorter incubation times and rapid brain accumulation of $\mathrm{PrPSc}^{\mathrm{Sc}}$ after inoculation with prions, compared to control wild-type (WT) mice [31], suggesting that the sortilin-mediated trafficking of $\mathrm{PrP}^{\mathrm{C}}$ and $\mathrm{PrP}^{\mathrm{Sc}}$ to lysosomes could be a host defense mechanism in prion diseases. Low-density lipoprotein receptor-related protein 1 has also been reported as a cargo receptor for $\mathrm{PrP}^{\mathrm{C}}$ for transport from the Golgi apparatus to the cell surface and from the cell surface to endosomes [32].

\subsection{Various Abnormal Phenotypes Are Spontaneously Observed in Prnp ${ }^{0 / 0}$ Mice}

$\operatorname{Prnp}^{0 / 0}$ mice are born with no obvious defects, indicating that $\operatorname{PrP}^{\mathrm{C}}$ could be dispensable for embryonic development $[11,33,34]$. However, various neurophysiological and neuropathological abnormalities have been reported in $\operatorname{Prnp}^{0 / 0}$ mice, including poor performance in certain behavioral tests [35], impaired long-term potentiation (LTP) in the hippocampal CA1 neurons [36], altered sleep and circadian rhythms [37], demyelination in spinal cords and peripheral nerves [38], and abnormal olfactory function $[39,40]$. These results suggest that $\operatorname{PrP}^{\mathrm{C}}$ is involved in various neuronal functions. However, normal LTP in $\operatorname{Prnp}^{0 / 0}$ mice has been reported by other investigators [41].

\subsection{The OR Region in the Cell-Protective Role of $\operatorname{Pr}^{C}$}

We and others have shown that $P r n p^{0 / 0}$ mice are vulnerable to ischemic brain, heart, or kidney damage, displaying higher apoptotic cell death and higher oxidative stress in the damaged tissues [42-46]. We also recently reported that $P r n p^{0 / 0}$ mice are highly sensitive to infection with influenza A viruses (IAVs), showing higher morbidity and mortality with higher inflammation, higher apoptotic cell death, and higher oxidative stress in their lungs [47]. Treatment with a scavenger for reactive oxygen species (ROS) or an inhibitor for ROS-generating xanthine oxidase rescued Prnp ${ }^{0 / 0}$ mice from lethal IAV infection [47]. In contrast, PrP molecules lacking the OR region failed to protect $P r n p^{0 / 0}$ mice from lethal IAV infection and ischemic brain damage [47,48]. These results suggest that $\mathrm{PrP}^{\mathrm{C}}$ could play a cell-protective role against oxidative stress through the OR region. The OR region is known to bind copper [49]. Indeed, the copper content and enzymatic activity of copper/zinc-dependent superoxide dismutase (SOD) were lower in Prnp ${ }^{0 / 0}$ lungs and brains than in control WT tissues [47,49]. It is thus possible that $\operatorname{PrP}^{\mathrm{C}}$ could function as a transporter of the OR region-bound copper to copper/zinc-SOD, thereby regulating enzyme activity and eventually protecting from oxidative stress. It was reported that $\operatorname{PrPC}^{C}$ itself might have SOD-like activity [50]. However, other investigators have failed to detect SOD activity in $\mathrm{PrPC}^{\mathrm{C}}$ in vitro and in vivo [51,52].

The OR region is also suggested to be involved in other cell-protective mechanisms of $\operatorname{PrP}^{\mathrm{C}}$. Overexpression of $\mathrm{PrP}^{\mathrm{C}}$, but not an OR-lacking $\mathrm{PrP}$ molecule, was shown to protect against Bax-mediated apoptosis in human primary neurons [53], suggesting that $\mathrm{PrP}^{\mathrm{C}}$ could function as an anti-apoptotic molecule through the OR region. Oh et al. also reported that autophagy was activated in $P r n p^{0 / 0}$ hippocampal neuronal cultured cells under serum deprivation, and that expression of $\operatorname{Pr} \mathrm{P}^{\mathrm{C}}$ prevented the activation of autophagy in the cells, but an OR-deleted PrP mutant did not [54], suggesting that $\operatorname{PrP}^{\mathrm{C}}$ could regulate autophagy activity in neuronal cells through the OR region. It remains to be determined if these functions of $\operatorname{PrPC}^{\mathrm{C}}$ are attributable to the activation of copper/zinc-SOD. 


\subsection{The Polybasic Region in the Function of $\operatorname{Pr} P^{C}$}

The polybasic region is also suggested to be involved in the anti-oxidative activity of $\operatorname{Pr} \mathrm{P}^{\mathrm{C}}$. Oxidative stress was shown to enhance cleavage of $\operatorname{Pr} \mathrm{P}^{\mathrm{C}}$, releasing the N-terminal fragment, termed N2, which encompasses residues 23-89 including the polybasic region [55], and the N2 fragment protected neuronal cells against oxidative stress through stimulation of MEK1 signaling [56]. Two proline residues in the polybasic region were shown to be important for the N2-mediated anti-oxidative activity [55]. Other roles have also been reported for the polybasic region including that it is involved in mediating the interaction of $\mathrm{PrPC}^{\mathrm{C}}$ with tubulin or glycosaminoglycan [57-60], the B-secretase-mediated cleavage of the Alzheimer's amyloid precursor protein [61], and DNA repair [62].

\section{The N-Terminal Domain of $\operatorname{PrP}^{\mathrm{C}}$ in Prion Disease}

\subsection{The Polybasic Region in Prion Disease}

Reconstituted Prnp ${ }^{0 / 0}$ mice by transgenic introduction of a mutant PrP with a deletion of the polybasic region residues 23-31, designated $\operatorname{Tg}(\operatorname{PrP} \Delta 23-31) / \operatorname{Prnp}{ }^{0 / 0}$ mice, were shown to develop prion disease with markedly elongated incubation times and delayed accumulation of $\operatorname{PrP}^{\mathrm{Sc}} \Delta 23-31$ in their brains after inoculation with RML scrapie prions (Table 1) [63]. $\operatorname{PrP}^{\mathrm{Sc}} \Delta 23-31$ accumulated in the brains of $\operatorname{Tg}(\operatorname{PrP} \Delta 23-31) / \operatorname{Prnp}^{0 / 0}$ mice showed similar resistance to PK to WT $\operatorname{PrP}^{\mathrm{Sc}}$ [63], suggesting that the polybasic region does not affect the PK-resistance of $\mathrm{PrP}^{\mathrm{Sc}}$. These results suggest that the polybasic region could play a crucial role in the pathogenesis of prion diseases. We have shown that $\operatorname{Tg}(\operatorname{PrP} \Delta 25-50) / \operatorname{Prnp}^{0 / 0}$ mice developed disease without elongated incubation times after infection with RML and 22L prions (Table 1) [64], suggesting that the remaining residues 23 and 24 in PrP $\Delta 25-50$ could be enough for the polybasic region to support prion pathogenesis. However, it was reported that incubation times were only slightly longer or not elongated at all in $\operatorname{Tg}(\operatorname{PrP} \Delta 23-26) / \operatorname{Prnp}{ }^{0 / 0}$ mice after infection with $127 \mathrm{~S}$ and LA19K scrapie prions and BSE prions (Table 1) [65]. PrP $\Delta 23-26$ includes intact residues 27-31, but lacks residues 23 and 24 in the polybasic region. It is thus possible that the polybasic region might require that both residues $23-24$ and 27-31 are intact to fully support prion pathogenesis [64]. Consistent with this idea, mutations of lysine residues at positions 24 and 27 together with a mutation of an arginine residue at position 25 rendered ovine PrP highly resistant to $127 \mathrm{~S}$ and LA19K scrapie prions and BSE prions (Table 1) [65]. We also showed that Prnp ${ }^{0 / 0}$ mice transgenic for mouse PrP with substitutions of lysine residues at positions 23, 24, and 27 to alanine residues, or PrP3K3A, markedly reduced their susceptibility to RML and 22L scrapie prions (Table 1) [66], suggesting that positively charged residues in residues 23-24 and 27-31 could be important for the polybasic region to support prion pathogenesis. No PK-resistant PrP3K3A was spontaneously produced in the brain of uninfected $\operatorname{Tg}(\operatorname{PrP} 3 \mathrm{~K} 3 \mathrm{~A}) / \operatorname{Prn} p^{0 / 0}$ mice [66], suggesting that mutations in the polybasic region might not cause structural changes in mutant PrPs.

Table 1. Effects of various mutations in the polybasic region of $\operatorname{PrP}^{C}$ on acquired prion diseases.

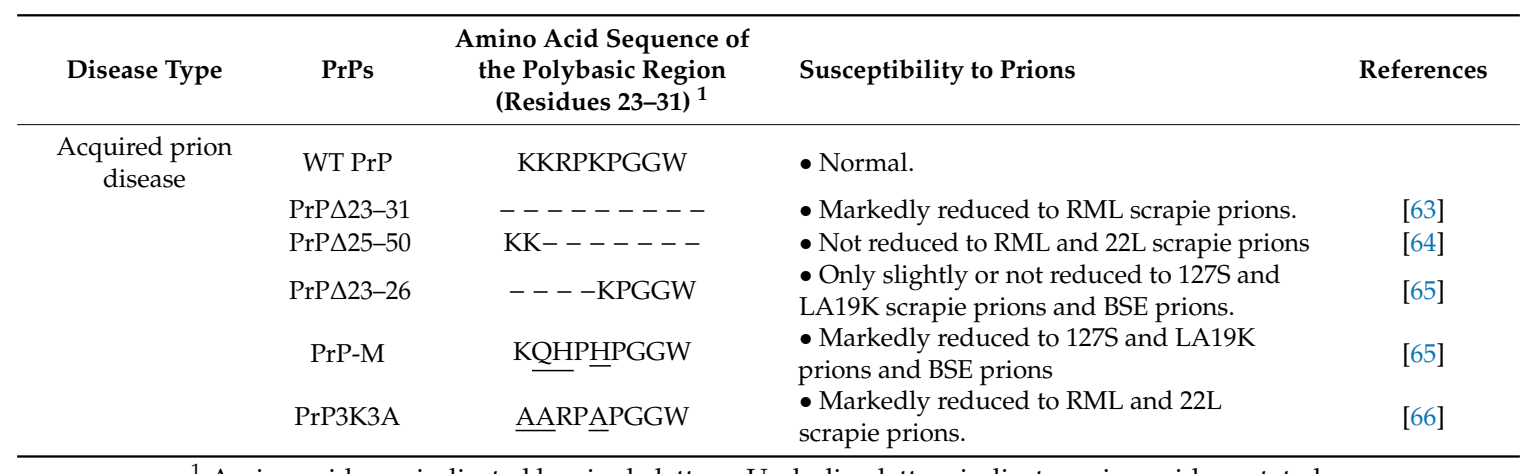

\footnotetext{
${ }^{1}$ Amino acids are indicated by single letters. Underline letters indicate amino acids mutated.
} 


\subsection{The OR Region in Prion Disease}

Insertion of various numbers of an OR sequence, ranging from one to nine, and deletion of one OR sequence in the OR region have been identified in patients with hereditary CJD [67]. Brain homogenates from patients with five, seven, or eight extra OR sequences in $\operatorname{PrP}$ can transmit the disease to animals after intracerebral inoculation [68]. This suggests that disruption of the integrity of the OR region by the insertion or deletion of the OR sequence could cause structural instability of mutated PrPs, ultimately leading to their spontaneous conversion to pathogenic, infectious PrPs. We failed to detect PK-resistant PrP in the brains of $\operatorname{Tg}(\operatorname{PrP} \Delta \mathrm{OR}) / \operatorname{Prnp}^{0 / 0}$ mice, which express PrP with a deletion of the OR region alone (Table 2) [69,70], suggesting that spontaneous conversion of mutated PrPs with extra OR sequences to PK-resistant PrPs could be due to gain-of-function, but not due to loss-of-function, of the mutated OR region. Consistent with this, $\mathrm{Tg}(\mathrm{PG} 14) / \mathrm{Prnp}^{0 / 0}$ mice, which express a PrP mutant with nine extra OR sequences in the OR region, developed spontaneous cerebellar neurodegeneration including granule cell death, with very slight but substantial accumulation of PK-resistant PrPSc PG14 in their brains (Table 2) [71,72]. However, $\operatorname{PrP}^{\mathrm{Sc}} \mathrm{PG} 14$ had no prion infectivity in animal bioassays (Table 2) [73]. Also, transgenic expression of bovine PrP with four extra OR sequences, or bo10OR-PrP, caused a slowly progressive neurological disorder with ataxia, vacuolization, gliosis, and cerebellar granule cell loss in Prnp ${ }^{0 / 0}$ mice (Table 2) [74]. Insoluble and slightly PK-resistant 10OR-PrPSc molecules accumulated in their brains, but no prion infectivity was found associated with the insoluble 10OR-PrPSc (Table 2) [74]. These results indicate that PrPPG14 and bo10OR-PrP spontaneously convert to PrPScPG14 and 10OR-PrPSc, respectively, with structural features shared with $\mathrm{PrP}^{\mathrm{Sc}}$ that are responsible for the neurotoxicity but not prion infectivity. These results also suggest that the structural features of $\mathrm{PrP}^{\mathrm{Sc}}$ that contribute to its neurotoxicity and prion infectivity are not identical.

Table 2. Effects of various mutations in the $\mathrm{OR}$ region of $\operatorname{PrP}^{\mathrm{C}}$ on hereditary and acquired prion diseases.

\begin{tabular}{|c|c|c|c|c|}
\hline Disease Type & PrPs & $\begin{array}{c}\text { Number of the OR } \\
\text { Sequence }\end{array}$ & Clinicopathological Features & References \\
\hline $\begin{array}{l}\text { Hereditary prion } \\
\text { disease }\end{array}$ & Bo10OR-PrP & $14^{1}$ & $\begin{array}{l}\text { - Spontaneously develop cerebellar } \\
\text { neurodegeneration. } \\
\text { - Accumulate very slightly but substantially } \\
\text { PK-resistant PrPScPG14 in the brain. } \\
\text { - No prion infectivity associated with } \mathrm{PrP}^{\mathrm{Sc}} \mathrm{PG} 14 \text {. } \\
\text { - Spontaneously develop cerebellar } \\
\text { neurodegeneration. } \\
\text { - Accumulate insoluble and slightly PK-resistant } \\
\text { 10OR-PrPSc in their brains. } \\
\text { - No prion infectivity associated with } \\
10 \mathrm{OR}-\mathrm{PrP}^{\mathrm{Sc}} \text {. }\end{array}$ & [71-73] \\
\hline Disease Type & PrPs & $\begin{array}{c}\text { Number of the OR } \\
\text { Sequence }\end{array}$ & Susceptibility to Prions & References \\
\hline \multirow[t]{4}{*}{$\begin{array}{l}\text { Acquired prion } \\
\text { disease }\end{array}$} & $\operatorname{PrP} \triangle \mathrm{OR}$ & $0^{1}$ & $\begin{array}{l}\text { - Reduced to BSE prions, but not to RML and } \\
\text { 22L scrapie prions. }\end{array}$ & {$[70]$} \\
\hline & Bo7OR-PrP & $7^{2}$ & - Increased to BSE prions. & [75] \\
\hline & Bo10OR-PrP & $10^{2}$ & - Increased to BSE prions. & [74] \\
\hline & $\operatorname{PrP}($ TetraH $>\mathrm{G})$ & $\begin{array}{l}5^{1} \text { (with } 4 \text { histidine } \\
\text { residues mutated to } \\
\text { glycine residues) }\end{array}$ & - Reduced to RML prions. & [76] \\
\hline
\end{tabular}

${ }^{1}$ Normal mouse $\operatorname{PrP}^{\mathrm{C}}$ contains 5 repeats of the OR sequence. ${ }^{2}$ Normal bovine $\mathrm{PrP}^{\mathrm{C}}$ contains 6 repeats of the OR sequence.

The OR region is also involved in prion infection. We have shown that $\operatorname{Tg}(\operatorname{PrP} \Delta \mathrm{OR}) / \operatorname{Prnp}{ }^{0 / 0}$ mice are highly resistant to BSE prions (Table 2) [70]. They developed the disease with markedly elongated incubation times with delayed accumulation of $\operatorname{PrP}^{S \mathrm{~S}} \Delta \mathrm{OR}$ in their brains after inoculation with BSE prions (Table 2) [70]. Consistent with our results, an increasing number of OR insertions contrarily enhances BSE pathogenesis in mice. Prnp ${ }^{0 / 0}$ mice expressing bovine PrP with one extra OR sequence had shortened incubation times when compared with $P r n p^{0 / 0}$ mice expressing WT bovine PrP, or bo6OR-PrP, after infection with BSE prions (Table 2) [75]. BSE-inoculated Tg(bo10OR-PrP)/Prnp ${ }^{0 / 0}$ mice were also shown to have further shortened incubation times when compared to BSE-inoculated 
$\operatorname{Tg}\left(\right.$ bo6OR-PrP)/Prnp ${ }^{0 / 0}$ mice (Table 2) [74]. These results suggest that the OR region could play a crucial role in BSE prions during the conversion of $\operatorname{PrP}^{\mathrm{C}}$ to $\operatorname{PrP}^{\mathrm{Sc}}$. In contrast, $\operatorname{Tg}(\operatorname{PrP} \Delta \mathrm{OR}) / \operatorname{Prnp} p^{0 / 0}$ mice remained susceptible to RML and 22L scrapie prions, developing the disease without elongated incubation times with slightly less $\operatorname{PrP}^{\mathrm{Sc}} \Delta \mathrm{OR}$ in their brains after infection with RML and 22L prions (Table 2) [70], suggesting that the OR region might be involved in prion pathogenesis in a strain-dependent manner. However, $\operatorname{Prn} p^{0 / 0}$ mice expressing $\operatorname{PrP}$ with histidine residues in the OR region replaced by glycine residues, termed $\operatorname{PrP}(\mathrm{TetraH}>\mathrm{G})$, showed significantly prolonged incubation times after infection with RML prions (Table 2) [76]. Further studies are needed to clarify whether or not the OR region might mediate strain-dependent prion pathogenesis.

\subsection{The Post-OR Region in Prion Diseases}

Three mutations in the post-OR region, including P102L (substitution of a proline residue to a leucine residue at position 102), P105L (substitution of a proline residue to a leucine residue at position 105), and A117V (substitution of an alanine residue to a valine residue at position 117), are associated with inherited human prion diseases [67], suggesting that the post-OR region also plays a role in prion diseases. $\operatorname{Tg}(\mathrm{PrP}-\mathrm{P} 101 \mathrm{~L})$ mice, which express high levels of mouse PrP-P101L, the analogous mutation to human PrP-P102L, have been shown to spontaneously develop prion disease-like diseases, with amyloid plaques, spongiform degeneration, and gliosis in their brains (Table 3) [77]. Brain homogenates from ill $\mathrm{Tg}(\mathrm{PrP}-\mathrm{P} 101 \mathrm{~L})$ mice transmitted the disease to $40 \%$ of $\operatorname{Tg}(\operatorname{PrP}-\mathrm{P} 101 \mathrm{~L})$ mice, which never spontaneously developed disease due to lower expression of the mutant protein, and $10 \%$ of hamsters, but not to WT CD-1 mice, after intracerebral inoculation (Table 3) [78], indicating that $\mathrm{PrP}^{\mathrm{Sc}}-\mathrm{P} 101 \mathrm{~L}$ could be infectious. Tg mice expressing mouse PrP-A116V (the human homologue of $\operatorname{PrP}-\mathrm{A} 117 \mathrm{~V}$ ) at six times the endogenous levels of $\operatorname{PrP}^{\mathrm{C}}$ also spontaneously developed progressive ataxia with vacuolation and PrP amyloid plaques in their brains (Table 3) [79]. The PrP molecules from $\mathrm{Tg}(\mathrm{PrP}-\mathrm{A} 116 \mathrm{~V})$ brains were partly insoluble and weakly protease-resistant (Table 3) [79]. No data are available regarding whether PK-resistant PrP-A116V is infectious.

The post-OR region could be also involved in prion infection. $\operatorname{Tg}(\operatorname{PrP} \Delta 32-80) / \operatorname{Prnp}{ }^{0 / 0}$ mice developed disease without elongation in incubation times and accumulated $\operatorname{PrP}^{\mathrm{Sc}} \Delta 32-80$ in their brains after infection with RML prions (Table 3) [80], suggesting that residues 32-80 are dispensable for $\operatorname{PrP}^{\mathrm{C}}$ to convert to $\operatorname{PrPSc}$ after prion infection. However, $\operatorname{Tg}(\operatorname{PrP} \Delta 32-93) / \operatorname{Prnp}^{0 / 0}$ mice, which express $\operatorname{PrP}$ with a deletion extending to the post-OR region at position 93 from the OR region at position 88, developed disease with longer incubation times and with lower levels of infectivity and $\operatorname{PrP}^{\mathrm{Sc}} \Delta 32-93$ in their brains after infection with RML prions (Table 3) [81]. Moreover, PrP with a deletion further extending to the post-OR region at position 106, or $\operatorname{PrP} \Delta 32-106$, neither converted to $\operatorname{Pr} \mathrm{P}^{\mathrm{Sc}}$ nor supported prion pathogenesis in $\operatorname{Prnp}{ }^{0 / 0}$ mice after intracerebral inoculation with RML prions (Table 3) [82]. These results suggest that the post-OR residues 91-106, which are completely deleted in $\operatorname{PrP} \Delta 32-106$ and partially in $\operatorname{PrP} \Delta 32-93$, but intact in PrP $\Delta 32-80$, could have a crucial role in prion infection. However, it remains to be determined if the resistance of $\operatorname{Tg}(\operatorname{PrP} \Delta 32-106) / \operatorname{Prnp}^{0 / 0}$ mice to RML prions could be due to deletion of the post-OR residues 91-96 alone or together with deletion of other residues.

Table 3. Effects of various mutations in the post-OR region of $\mathrm{PrP}^{\mathrm{C}}$ on hereditary and acquired prion diseases.

\begin{tabular}{|c|c|c|c|c|}
\hline Disease Type & PrPs & The Post-OR Sequence & Clinicopathological Features & References \\
\hline \multirow[t]{2}{*}{$\begin{array}{c}\text { Hereditary prion } \\
\text { disease }\end{array}$} & PrP-P101L & $\begin{array}{l}\text { Proline residue at } \\
\text { position } 101 \text { mutated to } \\
\text { leucine residue in } \\
\text { mouse PrP }\end{array}$ & $\begin{array}{l}\text { - Spontaneously develop prion } \\
\text { disease-like diseases. } \\
\text { - Accumulate weakly protease-resistant } \\
\text { PrP-P101L in the brain. } \\
\text { - Accumulate prion infectivity associated } \\
\text { with weakly protease-resistant PrP-P101L. }\end{array}$ & {$[77,78]$} \\
\hline & PrP-A116V & $\begin{array}{l}\text { Alanine residue at } \\
\text { position } 116 \text { mutated to } \\
\text { valine residue in } \\
\text { mouse } \operatorname{PrP}\end{array}$ & $\begin{array}{l}\text { - Spontaneously developed prion } \\
\text { disease-like diseases. } \\
\text { - Accumulate partly insoluble and weakly } \\
\text { protease-resistant PrP-A116V in the brain. } \\
\text { - No data available as to infectivity } \\
\text { associated with protease-resistant PrP-A116V. }\end{array}$ & [79] \\
\hline
\end{tabular}


Table 3. Cont.

\begin{tabular}{ccclc}
\hline Disease Type & PrPs & The Post-OR Sequence & Susceptibility to Prions & References \\
\hline $\begin{array}{c}\text { Acquired prion } \\
\text { disease }\end{array}$ & $\operatorname{PrP} \Delta 32-80$ & Intact & • Fully susceptible to RML scrapie prions. & [80] \\
& $\operatorname{PrP} \Delta 32-93$ & $\begin{array}{c}\text { The post-OR residues } \\
\text { 91-93 deleted }\end{array}$ & $\bullet$ Partially reduced to RML scrapie prions. & [81] \\
& $\operatorname{PrP} \Delta 32-106$ & $\begin{array}{c}\text { The post-OR residues } \\
\text { 91-106 deleted }\end{array}$ & $\bullet$ Resistant to RML scrapie prions. & [82] \\
\hline
\end{tabular}

\section{The N-Terminal Domain in Conversion of $\operatorname{PrPC}^{\mathrm{C}}$ to $\operatorname{PrP}^{\mathrm{Sc}}$}

The first step for conversion of $\operatorname{PrP}^{\mathrm{C}}$ to $\mathrm{PrP}^{\mathrm{Sc}}$ is an intermolecular interaction between both molecules. The polybasic region has been suggested to be involved in the binding of $\mathrm{PrP}^{\mathrm{C}}$ and/or $\mathrm{PrP}^{\mathrm{Sc}}$ to the extracellular matrix proteins glycosaminoglycans through the positively charged residues [58-60]. It is thus possible that the polybasic region might promote interaction between $\mathrm{PrP}^{\mathrm{C}}$ and $\mathrm{PrP}^{\mathrm{Sc}}$ by recruiting both molecules to glycosaminoglycans, thereby supporting conversion of $\operatorname{PrP}^{\mathrm{C}}$ to $\operatorname{Pr} \mathrm{P}^{\mathrm{Sc}}$ (Figure 2A). The polybasic region has also been suggested to mediate a direct interaction between $\mathrm{PrP}^{\mathrm{C}}$ and $\mathrm{PrP}^{\mathrm{Sc}}$, thereby promoting the conversion of $\mathrm{PrP}^{\mathrm{C}}$ to $\mathrm{PrP}^{\mathrm{Sc}}$ [63] (Figure 2B).

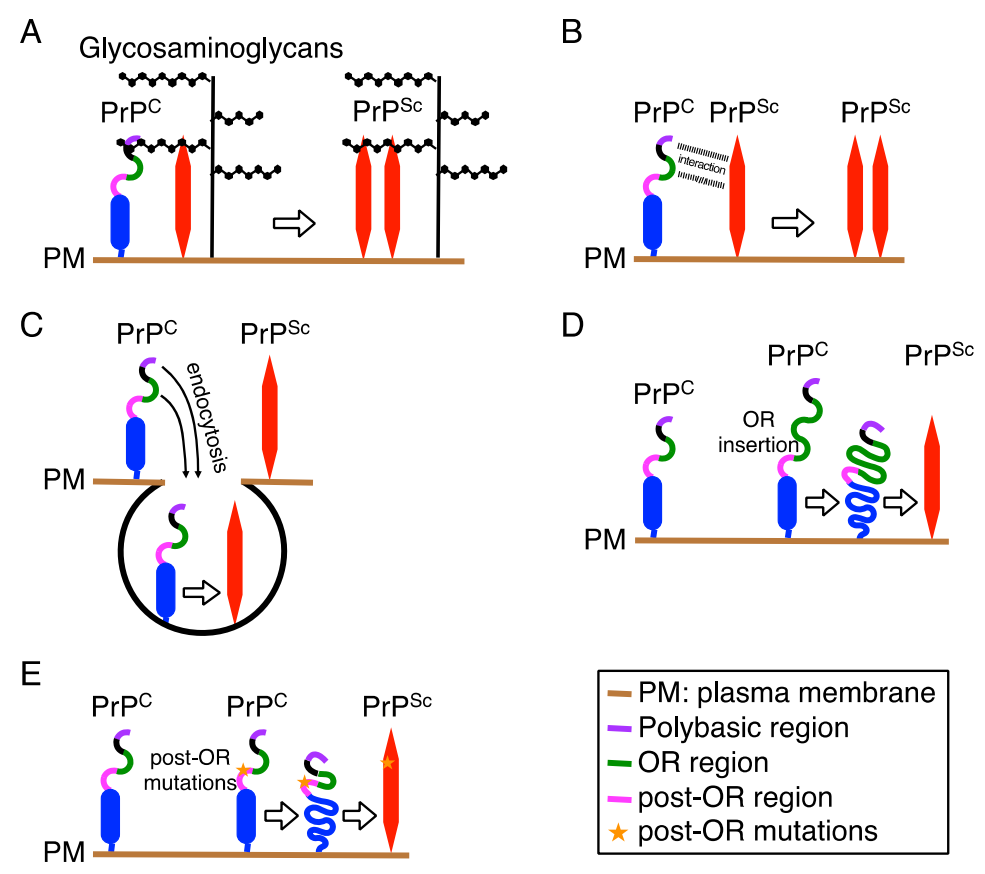

Figure 2. Possible roles of the $\mathrm{N}$-terminal regions in the conversion of $\mathrm{PrP}^{\mathrm{C}}$ into $\mathrm{PrP}^{\mathrm{Sc}}$. Upon conversion of $\mathrm{PrP}^{\mathrm{C}}$ into $\mathrm{PrP}^{\mathrm{Sc}}, \mathrm{PrP}^{\mathrm{C}}$ might interact with $\mathrm{PrP}^{\mathrm{Sc}}$ through glycosaminoglycans (A) or through the polybasic and $\mathrm{OR}$ regions $(\mathbf{B})$. (C) The polybasic and $\mathrm{OR}$ regions are also involved in endocytosis of $\mathrm{PrP}^{\mathrm{C}}$ to endosomal compartments, where $\mathrm{PrP}^{\mathrm{C}}$ is considered to convert into $\mathrm{PrP}^{\mathrm{Sc}}$. Extra OR sequences in the OR region (D) and point mutations in the post-OR region (E) might render mutated PrPs structurally unstable, ultimately leading to their spontaneous conversion to pathogenic PrPs.

The next step for conversion is a structural unfolding of the interacting $\operatorname{PrP}^{\mathrm{C}}$. $\operatorname{PrP}^{\mathrm{C}}$ is rich in $\alpha$-helix structures and soluble in non-ionic detergents [83]. In contrast, $\mathrm{PrP}^{\mathrm{Sc}}$ is abundant in $\mathrm{B}$-sheet structures and insoluble in non-ionic detergents, forming fibrils [83], suggesting that structural transition of $\alpha$-helices to $ß$-sheets in $\mathrm{PrP}^{\mathrm{C}}$ is an underlying mechanism of the conversion to $\mathrm{PrP}^{\mathrm{Sc}}$. Several structural models have been proposed for $\mathrm{PrP}^{\mathrm{Sc}}$ fibrils. The 4-rung $\mathrm{B}$-solenoid model postulates that a $\operatorname{Pr} \mathrm{P}^{\mathrm{Sc}}$ fibril consists of two intertwined protofilaments of $\mathrm{PrP}^{\mathrm{Sc}}$ molecules [84,85]. In this model, single $\mathrm{PrP}^{\mathrm{Sc}}$ molecules adopt a solenoid structure of four rungs, each rung including three $ß$-strands, running perpendicular to fibril axis, stacking each other. The upper and lower $B$-solenoid rungs of $\mathrm{PrP}^{\mathrm{Sc}}$ 
protofibrils could template an incoming unfolded $\mathrm{PrP}^{\mathrm{C}}$ molecule to create additional $ß$-solenoid rungs. Once a new $ß$-solenoid rung has formed, it continues to template until the unfolded $\operatorname{PrP}^{\mathrm{C}}$ molecule is completely converted to $\mathrm{PrP}^{\mathrm{Sc}}$ conformer. In the parallel in-register intermolecular B-sheet model, single $\mathrm{PrP}^{\mathrm{Sc}}$ molecules comprise the entire cross-section of a fibril, with many hairpins defined by natural and artificial disulfide bonds [86,87]. They are stacked parallel in-register and perpendicular to the fibril axis by forming intermolecular $\beta$-sheet interactions between them. Endocytic/lysosomal compartments are considered to be a site for conversion of $\operatorname{PrP}^{\mathrm{C}}$ to $\operatorname{PrP}^{\mathrm{Sc}}[88,89]$, suggesting that acidic conditions in the endosomal/lysosomal compartments might promote the structural unfolding of $\operatorname{PrP}^{\mathrm{C}}$. The polybasic and OR regions are involved in endocytosis of $\operatorname{PrP}^{\mathrm{C}}[30,90]$. It is thus possible that these regions might play a role in conversion of $\operatorname{PrP}^{\mathrm{C}}$ to $\mathrm{PrP}^{\mathrm{Sc}}$ by mediating endocytosis of $\operatorname{PrP}^{\mathrm{C}}$ to acidic endocytic/lysosomal compartments (Figure 2C). Insertion of extra OR sequences in the OR region or mutations in the post OR region are associated with spontaneous conversion of mutated PrPs to pathogenic PrPs, causing hereditary prion diseases in humans [67], suggesting that structural instability of the OR region or in the post-OR region might also be involved in the unfolding of the mutant PrPs (Figure 2D,E). Indeed, recombinant human PrPs with three or five extra OR sequences have been reported to spontaneously form aggregates [91]. Copper binding to recombinant mouse $\mathrm{PrP}$ was reported to cause novel intramolecular interactions, including those between the N-terminal residues $90-120$ and the C-terminal residues 144-147 and its nearby residues 139-143, and between the $\mathrm{N}$-terminal region comprising the OR region and the C-terminal residues 174-185 [92], suggesting that copper binding might also be involved in the unfolding of $\operatorname{PrP}^{\mathrm{C}}$. Copper is able to bind to histidine residues located in the OR and post-OR regions [76]. We have shown that, while $\operatorname{Tg}(\operatorname{PrP} \Delta \mathrm{OR}) / \operatorname{Prnp} 0 / 0$ mice were highly resistant to BSE prions, they still remained susceptible to RML and 22L prions [70], suggesting that copper binding to histidine residues in the OR region might be irrelevant to the unfolding of $\mathrm{PrP}^{\mathrm{C}}$. Indeed, it has been shown that histidine residues in the post-OR could be important for conversion of $\mathrm{PrP}^{\mathrm{C}}$ to $\mathrm{PrP}^{\mathrm{Sc}}$ in acidic conditions [93].

\section{The N-Terminal Domain and Neurotoxic PrP Molecules}

The neurotoxic mechanism of $\mathrm{PrP}^{\mathrm{Sc}}$ remains largely unknown. However, there have been several reports of neurotoxic PrP molecules causing prion disease-like neurodegeneration, giving rise to an interesting possibility that these neurotoxic PrP molecules might share their neurotoxic mechanism with $\mathrm{PrP}^{\mathrm{Sc}}$. In addition to a GPI-anchored extracellular form of $\mathrm{PrP}^{\mathrm{C}}$, another form of $\mathrm{PrP}$, termed ${ }^{\mathrm{Ctm}} \mathrm{PrP}$, has been reported [94]. ${ }^{\mathrm{Ctm}} \mathrm{PrP}$ is a transmembrane form of PrP, with the $\mathrm{N}$-terminus facing the cytoplasm and the C-terminus exposed extracellularly. Increased hydrophobicity in the post-OR region by mutations that cause residues to become hydrophobic, including the mutation in hereditary prion disease (A117V), increase the ratio of ${ }^{\mathrm{t} t m} \operatorname{PrP}$ to total forms of PrP molecules in neuronal cells [94]. Interestingly, transgenic mice expressing these mutant PrPs spontaneously develop prion disease-like neurodegeneration with focal vacuolar degeneration in the neuropil and astrocytic gliosis [94]. Moreover, the ratio of ${ }^{\mathrm{Ctm}} \mathrm{PrP}$ was also reported to increase in the brains of mice infected with prions [95]. These results suggest that ${ }^{\mathrm{Ctm}} \mathrm{PrP}$ might be responsible for neurodegeneration in prion diseases. However, ${ }^{C t m} \operatorname{PrP}$ from transgenic mice is not infectious [94].

Other neurotoxic PrP molecules have also been reported. It was shown that $\operatorname{Prnp}{ }^{0 / 0}$ mice transgenic for PrP with a deletion of the N-terminal residues 32-121 or 32-134, which includes the OR region and a section of the post-OR region, spontaneously developed cerebellar neurodegeneration, with marked granule cell death [96]. Other investigators also showed that $\operatorname{Prnp} p^{0 / 0}$ mice expressing a PrP molecule, designated $\Delta \mathrm{CR}$, that harbors a deletion of residues 105-125, developed cerebellar neurodegeneration [97], suggesting that deletion of the post-OR residues 105-125 alone could be responsible for the neurodegeneration in $\operatorname{Prn} p^{0 / 0}$ mice expressing $\operatorname{PrP} \Delta 21-121$ and $\operatorname{PrP} \Delta 32-134$. Interestingly, the neurotoxicity of these mutant PrPs in $\operatorname{Prnp}^{0 / 0}$ mice is abrogated by co-expression of WT $\operatorname{PrP} P^{C}[96,97]$, suggesting that, while the toxic PrP molecules generate a neurotoxic signal, WT PrPC transduces a neuroprotective signal to antagonize the neurotoxic signal of the mutant PrPs. It was 
shown that, in contrast to $\operatorname{PrP} \Delta 32-134, \operatorname{PrP} \Delta 23-134$ was not neurotoxic in $\operatorname{Prnp} p^{0 / 0}$ mice, suggesting that the polybasic region residues 23-31, which remain intact in toxic $\operatorname{PrP} \Delta 32-134$ but not in non-toxic $\operatorname{PrP} \Delta 23-134$, are critical for the neurotoxicity of mutant PrPs [98,99]. Patch-clamp electrophysiological experiments revealed that $\triangle \mathrm{CR}$ induced abnormal spontaneous ionic currents in various cultured cells and neurons through the polybasic region, and that these currents were suppressed by co-expression of WT PrPC $[100,101]$, suggesting that the abnormal ionic currents might be the neurotoxic signal of the mutant PrPs. It would be thus worthy to investigate whether $\mathrm{PrP}^{\mathrm{Sc}}$ could generate similar abnormal currents in neurons.

\section{Conclusions}

It has been shown that the non-structural, flexible N-terminal domain, which includes various specific regions such as the polybasic region, OR regions, and post-OR region, has a role in not only the normal function of $\operatorname{PrP}^{\mathrm{C}}$ but also in the pathogenesis of prion diseases through regulation of the conversion of $\operatorname{PrP}^{\mathrm{C}}$ to $\operatorname{PrP}^{\mathrm{Sc}}$ and the neurotoxicity of $\operatorname{PrP}^{\mathrm{Sc}}$. Further elucidation of the exact mechanism of how each of the $\mathrm{N}$-terminal regions could regulate the normal function of $\mathrm{PrP}^{\mathrm{C}}$ and prion pathogenesis would be of great help for understanding the function of $\operatorname{PrPC}^{\mathrm{C}}$ and prion pathogenesis, and eventually for developing therapeutics for prion diseases.

Author Contributions: Conceptualization, H.H. and S.S.; writing, H.H. and S.S.; funding acquisition, H.H. and S.S. All authors have read and agreed to the published version of the manuscript.

Funding: This work was supported in part by JSPS KAKENHI Grant Number 18K07499, Brain Science Foundation, Takeda Science Foundation, and The Ichiro Kanehara Foundation to H.H. and JSPS KAKENHI Grant Number $19 \mathrm{H} 03548$ to S.S.

Conflicts of Interest: The authors declare no conflict of interest.

\section{Abbreviations}

$\begin{array}{ll}\text { PrP } & \text { Prion protein } \\ \text { OR } & \text { Octapeptide repeat } \\ \text { WT } & \text { Wild-type } \\ \text { CJD } & \text { Creutzfeldt-Jakob disease }\end{array}$

\section{References}

1. Aguzzi, A.; Baumann, F.; Bremer, J. The prion's elusive reason for being. Annu. Rev. Neurosci. 2008, 31, 439-477. [CrossRef] [PubMed]

2. Prusiner, S.B. The prion diseases. Brain Pathol. 1998, 8, 499-513. [CrossRef] [PubMed]

3. Scheckel, C.; Aguzzi, A. Prions, prionoids and protein misfolding disorders. Nat. Rev. Genet. 2018, 19, 405-418. [CrossRef] [PubMed]

4. Giles, K.; Olson, S.H.; Prusiner, S.B. Developing Therapeutics for PrP Prion Diseases. Cold Spring Harb. Perspect. Med. 2017, 7, a023747. [CrossRef] [PubMed]

5. Prusiner, S.B. Early evidence that a protease-resistant protein is an active component of the infectious prion. Cell 2004, 116, S109. [CrossRef]

6. Prusiner, S.B. Novel proteinaceous infectious particles cause scrapie. Science 1982, 216, 136-144. [CrossRef]

7. Igel-Egalon, A.; Bohl, J.; Moudjou, M.; Herzog, L.; Reine, F.; Rezaei, H.; Beringue, V. Heterogeneity and Architecture of Pathological Prion Protein Assemblies: Time to Revisit the Molecular Basis of the Prion Replication Process? Viruses 2019, 11, 429. [CrossRef]

8. Bueler, H.; Aguzzi, A.; Sailer, A.; Greiner, R.A.; Autenried, P.; Aguet, M.; Weissmann, C. Mice devoid of PrP are resistant to scrapie. Cell 1993, 73, 1339-1347. [CrossRef]

9. Prusiner, S.B.; Groth, D.; Serban, A.; Koehler, R.; Foster, D.; Torchia, M.; Burton, D.; Yang, S.L.; DeArmond, S.J. Ablation of the prion protein (PrP) gene in mice prevents scrapie and facilitates production of anti-PrP antibodies. Proc. Natl. Acad. Sci. USA 1993, 90, 10608-10612. [CrossRef] 
10. Manson, J.C.; Clarke, A.R.; McBride, P.A.; McConnell, I.; Hope, J. PrP gene dosage determines the timing but not the final intensity or distribution of lesions in scrapie pathology. Neurodegeneration 1994, 3, 331-340.

11. Sakaguchi, S.; Katamine, S.; Shigematsu, K.; Nakatani, A.; Moriuchi, R.; Nishida, N.; Kurokawa, K.; Nakaoke, R.; Sato, H.; Jishage, K.; et al. Accumulation of proteinase K-resistant prion protein $(\operatorname{PrP})$ is restricted by the expression level of normal PrP in mice inoculated with a mouse-adapted strain of the Creutzfeldt-Jakob disease agent. J. Virol. 1995, 69, 7586-7592. [CrossRef] [PubMed]

12. Schatzl, H.M.; Da Costa, M.; Taylor, L.; Cohen, F.E.; Prusiner, S.B. Prion protein gene variation among primates. J. Mol. Biol. 1995, 245, 362-374. [CrossRef] [PubMed]

13. Oesch, B.; Westaway, D.; Walchli, M.; McKinley, M.P.; Kent, S.B.; Aebersold, R.; Barry, R.A.; Tempst, P.; Teplow, D.B.; Hood, L.E.; et al. A cellular gene encodes scrapie PrP 27-30 protein. Cell. 1985, 40, 735-746. [CrossRef]

14. Riek, R.; Hornemann, S.; Wider, G.; Glockshuber, R.; Wuthrich, K. NMR characterization of the full-length recombinant murine prion protein, $\mathrm{mPrP}(23-231)$. FEBS Lett. 1997, 413, 282-288. [CrossRef]

15. Donne, D.G.; Viles, J.H.; Groth, D.; Mehlhorn, I.; James, T.L.; Cohen, F.E.; Prusiner, S.B.; Wright, P.E.; Dyson, H.J. Structure of the recombinant full-length hamster prion protein $\operatorname{PrP}(29-231)$ : The N terminus is highly flexible. Proc. Natl. Acad. Sci. USA 1997, 94, 13452-13457. [CrossRef] [PubMed]

16. Calzolai, L.; Lysek, D.A.; Perez, D.R.; Guntert, P.; Wuthrich, K. Prion protein NMR structures of chickens, turtles, and frogs. Proc. Natl. Acad. Sci. USA 2005, 102, 651-655. [CrossRef] [PubMed]

17. Prusiner, S.B. Molecular biology of prion diseases. Science 1991, 252, 1515-1522. [CrossRef]

18. Hackl, S.; Becker, C.F.W. Prion protein-Semisynthetic prion protein (PrP) variants with posttranslational modifications. J. Pept. Sci. 2019, 25, e3216. [CrossRef]

19. Stahl, N.; Borchelt, D.R.; Hsiao, K.; Prusiner, S.B. Scrapie prion protein contains a phosphatidylinositol glycolipid. Cell 1987, 51, 229-240. [CrossRef]

20. Stahl, N.; Baldwin, M.A.; Hecker, R.; Pan, K.M.; Burlingame, A.L.; Prusiner, S.B. Glycosylinositol phospholipid anchors of the scrapie and cellular prion proteins contain sialic acid. Biochemical 1992, 31, 5043-5053. [CrossRef]

21. Hebert, D.N.; Molinari, M. In and out of the ER: Protein folding, quality control, degradation, and related human diseases. Physiol. Rev. 2007, 87, 1377-1408. [CrossRef] [PubMed]

22. Rapoport, T.A. Protein translocation across the eukaryotic endoplasmic reticulum and bacterial plasma membranes. Nature 2007, 450, 663-669. [CrossRef] [PubMed]

23. Almanza, A.; Carlesso, A.; Chintha, C.; Creedican, S.; Doultsinos, D.; Leuzzi, B.; Luis, A.; McCarthy, N.; Montibeller, L.; More, S.; et al. Endoplasmic reticulum stress signalling - From basic mechanisms to clinical applications. FEBS J. 2019, 286, 241-278. [CrossRef] [PubMed]

24. Needham, P.G.; Guerriero, C.J.; Brodsky, J.L. Chaperoning Endoplasmic Reticulum-Associated Degradation (ERAD) and Protein Conformational Diseases. Cold Spring Harb. Perspect. Biol. 2019, 11, a033928. [CrossRef] [PubMed]

25. Puig, B.; Altmeppen, H.C.; Linsenmeier, L.; Chakroun, K.; Wegwitz, F.; Piontek, U.K.; Tatzelt, J.; Bate, C.; Magnus, T.; Glatzel, M. GPI-anchor signal sequence influences $\operatorname{PrP}^{\mathrm{C}}$ sorting, shedding and signalling, and impacts on different pathomechanistic aspects of prion disease in mice. PLoS Pathog. 2019, 15, e1007520. [CrossRef]

26. Wulf, M.A.; Senatore, A.; Aguzzi, A. The biological function of the cellular prion protein: An update. BMC Biol. 2017, 15, 34. [CrossRef]

27. Peters, P.J.; Mironov, A., Jr.; Peretz, D.; van Donselaar, E.; Leclerc, E.; Erpel, S.; DeArmond, S.J.; Burton, D.R.; Williamson, R.A.; Vey, M.; et al. Trafficking of prion proteins through a caveolae-mediated endosomal pathway. J. Cell Biol. 2003, 162, 703-717. [CrossRef]

28. Campana, V.; Sarnataro, D.; Zurzolo, C. The highways and byways of prion protein trafficking. Trends Cell Biol. 2005, 15, 102-111. [CrossRef]

29. Vilette, D.; Courte, J.; Peyrin, J.M.; Coudert, L.; Schaeffer, L.; Andreoletti, O.; Leblanc, P. Cellular mechanisms responsible for cell-to-cell spreading of prions. Cell Mol. Life Sci. 2018, 75, 2557-2574. [CrossRef]

30. Taylor, D.R.; Watt, N.T.; Perera, W.S.; Hooper, N.M. Assigning functions to distinct regions of the N-terminus of the prion protein that are involved in its copper-stimulated, clathrin-dependent endocytosis. J. Cell Sci. 2005, 118, 5141-5153. [CrossRef] 
31. Uchiyama, K.; Tomita, M.; Yano, M.; Chida, J.; Hara, H.; Das, N.R.; Nykjaer, A.; Sakaguchi, S. Prions amplify through degradation of the VPS10P sorting receptor sortilin. PLoS Pathog. 2017, 13, e1006470. [CrossRef] [PubMed]

32. Taylor, D.R.; Hooper, N.M. The low-density lipoprotein receptor-related protein 1 (LRP1) mediates the endocytosis of the cellular prion protein. Biochem. J. 2007, 402, 17-23. [CrossRef]

33. Bueler, H.; Fischer, M.; Lang, Y.; Bluethmann, H.; Lipp, H.P.; DeArmond, S.J.; Prusiner, S.B.; Aguet, M.; Weissmann, C. Normal development and behaviour of mice lacking the neuronal cell-surface PrP protein. Nature 1992, 356, 577-582. [CrossRef] [PubMed]

34. Manson, J.C.; Clarke, A.R.; Hooper, M.L.; Aitchison, L.; McConnell, I.; Hope, J. 129/Ola mice carrying a null mutation in PrP that abolishes mRNA production are developmentally normal. Mol. Neurobiol. 1994, 8, 121-127. [CrossRef] [PubMed]

35. Nishida, N.; Katamine, S.; Shigematsu, K.; Nakatani, A.; Sakamoto, N.; Hasegawa, S.; Nakaoke, R.; Atarashi, R.; Kataoka, Y.; Miyamoto, T. Prion protein is necessary for latent learning and long-term memory retention. Cell Mol. Neurobiol. 1997, 17, 537-545. [CrossRef] [PubMed]

36. Collinge, J.; Whittington, M.A.; Sidle, K.C.; Smith, C.J.; Palmer, M.S.; Clarke, A.R.; Jefferys, J.G. Prion protein is necessary for normal synaptic function. Nature 1994, 370, 295-297. [CrossRef]

37. Tobler, I.; Gaus, S.E.; Deboer, T.; Achermann, P.; Fischer, M.; Rulicke, T.; Moser, M.; Oesch, B.; McBride, P.A.; Manson, J.C. Altered circadian activity rhythms and sleep in mice devoid of prion protein. Nature 1996, 380, 639-642. [CrossRef]

38. Nishida, N.; Tremblay, P.; Sugimoto, T.; Shigematsu, K.; Shirabe, S.; Petromilli, C.; Erpel, S.P.; Nakaoke, R.; Atarashi, R.; Houtani, T.; et al. A mouse prion protein transgene rescues mice deficient for the prion protein gene from purkinje cell degeneration and demyelination. Lab. Investig. 1999, 79, 689-697.

39. Kim, C.K.; Sakudo, A.; Taniuchi, Y.; Shigematsu, K.; Kang, C.B.; Saeki, K.; Matsumoto, Y.; Sakaguchi, S.; Itohara, S.; Onodera, T. Late-onset olfactory deficits and mitral cell loss in mice lacking prion protein with ectopic expression of Doppel. Int. J. Mol. Med. 2007, 20, 169-176. [CrossRef]

40. Le Pichon, C.E.; Valley, M.T.; Polymenidou, M.; Chesler, A.T.; Sagdullaev, B.T.; Aguzzi, A.; Firestein, S. Olfactory behavior and physiology are disrupted in prion protein knockout mice. Nat. Neurosci. 2009, 12, 60-69. [CrossRef]

41. Lledo, P.M.; Tremblay, P.; DeArmond, S.J.; Prusiner, S.B.; Nicoll, R.A. Mice deficient for prion protein exhibit normal neuronal excitability and synaptic transmission in the hippocampus. Proc. Natl. Acad. Sci. USA 1996, 93, 2403-2407. [CrossRef] [PubMed]

42. Weise, J.; Crome, O.; Sandau, R.; Schulz-Schaeffer, W.; Bahr, M.; Zerr, I. Upregulation of cellular prion protein $\left(\mathrm{PrP}^{\mathrm{C}}\right)$ after focal cerebral ischemia and influence of lesion severity. Neurosci. Lett. 2004, 372, 146-150. [CrossRef] [PubMed]

43. McLennan, N.F.; Brennan, P.M.; McNeill, A.; Davies, I.; Fotheringham, A.; Rennison, K.A.; Ritchie, D.; Brannan, F.; Head, M.W.; Ironside, J.W.; et al. Prion protein accumulation and neuroprotection in hypoxic brain damage. Am. J. Pathol. 2004, 165, 227-235. [CrossRef]

44. Sakurai-Yamashita, Y.; Sakaguchi, S.; Yoshikawa, D.; Okimura, N.; Masuda, Y.; Katamine, S.; Niwa, M. Female-specific neuroprotection against transient brain ischemia observed in mice devoid of prion protein is abolished by ectopic expression of prion protein-like protein. Neuroscience 2005, 136, 281-287. [CrossRef] [PubMed]

45. Zhang, B.; Cowden, D.; Zhang, F.; Yuan, J.; Siedlak, S.; Abouelsaad, M.; Zeng, L.; Zhou, X.; O'Toole, J.; Das, A.S.; et al. Prion Protein Protects against Renal Ischemia/Reperfusion Injury. PLoS ONE 2015, 10, e0136923.

46. Zanetti, F.; Carpi, A.; Menabo, R.; Giorgio, M.; Schulz, R.; Valen, G.; Baysa, A.; Massimino, M.L.; Sorgato, M.C.; Bertoli, A.; et al. The cellular prion protein counteracts cardiac oxidative stress. Cardiovasc. Res. 2014, 104, 93-102. [CrossRef]

47. Chida, J.; Hara, H.; Yano, M.; Uchiyama, K.; Das, N.R.; Takahashi, E.; Miyata, H.; Tomioka, Y.; Ito, T.; Kido, H.; et al. Prion protein protects mice from lethal infection with influenza A viruses. PLoS Pathog. 2018, 14, e1007049. [CrossRef] [PubMed]

48. Mitteregger, G.; Vosko, M.; Krebs, B.; Xiang, W.; Kohlmannsperger, V.; Nolting, S.; Hamann, G.F.; Kretzschmar, H.A. The role of the octarepeat region in neuroprotective function of the cellular prion protein. Brain Pathol. 2007, 17, 174-183. [CrossRef] [PubMed] 
49. Brown, D.R.; Qin, K.; Herms, J.W.; Madlung, A.; Manson, J.; Strome, R.; Fraser, P.E.; Kruck, T.; von Bohlen, A.; Schulz-Schaeffer, W.; et al. The cellular prion protein binds copper in vivo. Nature 1997, 390, $684-687$. [CrossRef] [PubMed]

50. Brown, D.R.; Wong, B.S.; Hafiz, F.; Clive, C.; Haswell, S.J.; Jones, I.M. Normal prion protein has an activity like that of superoxide dismutase. Biochem. J. 1999, 344,1-5. [CrossRef]

51. Jones, S.; Batchelor, M.; Bhelt, D.; Clarke, A.R.; Collinge, J.; Jackson, G.S. Recombinant prion protein does not possess SOD-1 activity. Biochem. J. 2005, 392, 309-312. [CrossRef] [PubMed]

52. Hutter, G.; Heppner, F.L.; Aguzzi, A. No superoxide dismutase activity of cellular prion protein In vivo. J. Biol. Chem. 2003, 384, 1279-1285. [CrossRef]

53. Bounhar, Y.; Zhang, Y.; Goodyer, C.G.; LeBlanc, A. Prion protein protects human neurons against Bax-mediated apoptosis. J. Biol. Chem. 2001, 276, 39145-39149. [CrossRef]

54. Oh, J.M.; Shin, H.Y.; Park, S.J.; Kim, B.H.; Choi, J.K.; Choi, E.K.; Carp, R.I.; Kim, Y.S. The involvement of cellular prion protein in the autophagy pathway in neuronal cells. Mol. Cell Neurosci. 2008, 39, $238-247$. [CrossRef] [PubMed]

55. Haigh, C.L.; Drew, S.C.; Boland, M.P.; Masters, C.L.; Barnham, K.J.; Lawson, V.A.; Collins, S.J. Dominant roles of the polybasic proline motif and copper in the PrP23-89-mediated stress protection response. J. Cell Sci. 2009, 122, 1518-1528. [CrossRef] [PubMed]

56. Haigh, C.L.; Tumpach, C.; Drew, S.C.; Collins, S.J. The Prion Protein N1 and N2 Cleavage Fragments Bind to Phosphatidylserine and Phosphatidic Acid; Relevance to Stress-Protection Responses. PLoS ONE 2015, 10, e0134680. [CrossRef]

57. Osiecka, K.M.; Nieznanska, H.; Skowronek, K.J.; Karolczak, J.; Schneider, G.; Nieznanski, K. Prion protein region 23-32 interacts with tubulin and inhibits microtubule assembly. Proteins 2009, 77, 279-296. [CrossRef]

58. Pan, T.; Wong, B.S.; Liu, T.; Li, R.; Petersen, R.B.; Sy, M.S. Cell-surface prion protein interacts with glycosaminoglycans. Biochem. J. 2002, 368, 81-90. [CrossRef]

59. Warner, R.G.; Hundt, C.; Weiss, S.; Turnbull, J.E. Identification of the heparan sulfate binding sites in the cellular prion protein. J. Biol. Chem. 2002, 277, 18421-18430. [CrossRef]

60. Taubner, L.M.; Bienkiewicz, E.A.; Copie, V.; Caughey, B. Structure of the flexible amino-terminal domain of prion protein bound to a sulfated glycan. J. Mol. Biol. 2010, 395, 475-490. [CrossRef]

61. Parkin, E.T.; Watt, N.T.; Hussain, I.; Eckman, E.A.; Eckman, C.B.; Manson, J.C.; Baybutt, H.N.; Turner, A.J.; Hooper, N.M. Cellular prion protein regulates beta-secretase cleavage of the Alzheimer's amyloid precursor protein. Proc. Natl. Acad. Sci. USA 2007, 104, 11062-11067. [CrossRef] [PubMed]

62. Bravard, A.; Auvre, F.; Fantini, D.; Bernardino-Sgherri, J.; Sissoeff, L.; Daynac, M.; Xu, Z.; Etienne, O.; Dehen, C.; Comoy, E.; et al. The prion protein is critical for DNA repair and cell survival after genotoxic stress. Nucleic Acids Res. 2015, 43, 904-916. [CrossRef] [PubMed]

63. Turnbaugh, J.A.; Unterberger, U.; Saa, P.; Massignan, T.; Fluharty, B.R.; Bowman, F.P.; Miller, M.B.; Supattapone, S.; Biasini, E.; Harris, D.A. The N-terminal, polybasic region of $\operatorname{PrP}^{\mathrm{C}}$ dictates the efficiency of prion propagation by binding to $\mathrm{PrP}^{\mathrm{Sc}}$. J. Neurosci. 2012, 32, 8817-8830. [CrossRef] [PubMed]

64. Das, N.R.; Miyata, H.; Hara, H.; Uchiyama, K.; Chida, J.; Yano, M.; Watanabe, H.; Kondoh, G.; Sakaguchi, S. Effects of prion protein devoid of the N-terminal residues $25-50$ on prion pathogenesis in mice. Arch. Virol. 2017, 162, 1867-1876. [CrossRef] [PubMed]

65. Khalife, M.; Reine, F.; Paquet-Fifield, S.; Castille, J.; Herzog, L.; Vilotte, M.; Moudjou, M.; Moazami-Goudarzi, K.; Makhzami, S.; Passet, B.; et al. Mutated but Not Deleted Ovine PrPC N-Terminal Polybasic Region Strongly Interferes with Prion Propagation in Transgenic Mice. J. Virol. 2016, 90, 1638-1646. [CrossRef]

66. Das, N.R.; Miyata, H.; Hara, H.; Chida, J.; Uchiyama, K.; Masujin, K.; Watanabe, H.; Kondoh, G.; Sakaguchi, S. The N-Terminal Polybasic Region of Prion Protein Is Crucial in Prion Pathogenesis Independently of the Octapeptide Repeat Region. Mol. Neurobiol. 2020, 57, 1203-1216. [CrossRef]

67. Prusiner, S.B. Genetic and infectious prion diseases. Arch. Neurol. 1993, 50, 1129-1153. [CrossRef]

68. Brown, P.; Gibbs, C.J., Jr.; Rodgers-Johnson, P.; Asher, D.M.; Sulima, M.P.; Bacote, A.; Goldfarb, L.G.; Gajdusek, D.C. Human spongiform encephalopathy: The National Institutes of Health series of 300 cases of experimentally transmitted disease. Ann. Neurol. 1994, 35, 513-529. [CrossRef] 
69. Yamaguchi, Y.; Miyata, H.; Uchiyama, K.; Ootsuyama, A.; Inubushi, S.; Mori, T.; Muramatsu, N.; Katamine, S.; Sakaguchi, S. Biological and biochemical characterization of mice expressing prion protein devoid of the octapeptide repeat region after infection with prions. PLoS ONE 2012, 7, e43540. [CrossRef]

70. Hara, H.; Miyata, H.; Das, N.R.; Chida, J.; Yoshimochi, T.; Uchiyama, K.; Watanabe, H.; Kondoh, G.; Yokoyama, T.; Sakaguchi, S. Prion Protein Devoid of the Octapeptide Repeat Region Delays Bovine Spongiform Encephalopathy Pathogenesis in Mice. J. Virol. 2017, 92, e01368-17. [CrossRef]

71. Chiesa, R.; Piccardo, P.; Ghetti, B.; Harris, D.A. Neurological illness in transgenic mice expressing a prion protein with an insertional mutation. Neuron 1998, 21, 1339-1351. [CrossRef]

72. Chiesa, R.; Drisaldi, B.; Quaglio, E.; Migheli, A.; Piccardo, P.; Ghetti, B.; Harris, D.A. Accumulation of protease-resistant prion protein (PrP) and apoptosis of cerebellar granule cells in transgenic mice expressing a PrP insertional mutation. Proc. Natl. Acad. Sci. USA 2000, 97, 5574-5579. [CrossRef] [PubMed]

73. Biasini, E.; Seegulam, M.E.; Patti, B.N.; Solforosi, L.; Medrano, A.Z.; Christensen, H.M.; Senatore, A.; Chiesa, R.; Williamson, R.A.; Harris, D.A. Non-infectious aggregates of the prion protein react with several PrPSc-Directed antibodies. J. Neurochem. 2008, 105, 2190-2204. [CrossRef] [PubMed]

74. Castilla, J.; Gutierrez-Adan, A.; Brun, A.; Pintado, B.; Salguero, F.J.; Parra, B.; Segundo, F.D.; Ramirez, M.A.; Rabano, A.; Cano, M.J.; et al. Transgenic mice expressing bovine PrP with a four extra repeat octapeptide insert mutation show a spontaneous, non-transmissible, neurodegenerative disease and an expedited course of BSE infection. FEBS Lett. 2005, 579, 6237-6246. [CrossRef]

75. Castilla, J.; Gutierrez-Adan, A.; Brun, A.; Pintado, B.; Parra, B.; Ramirez, M.A.; Salguero, F.J.; Diaz San Segundo, F.; Rabano, A.; Cano, M.J.; et al. Different behavior toward bovine spongiform encephalopathy infection of bovine prion protein transgenic mice with one extra repeat octapeptide insert mutation. J. Neurosci. 2004, 24, 2156-2164. [CrossRef]

76. Eigenbrod, S.; Frick, P.; Bertsch, U.; Mitteregger-Kretzschmar, G.; Mielke, J.; Maringer, M.; Piening, N.; Hepp, A.; Daude, N.; Windl, O.; et al. Substitutions of PrP N-terminal histidine residues modulate scrapie disease pathogenesis and incubation time in transgenic mice. PLoS ONE 2017, 12, e0188989. [CrossRef]

77. Hsiao, K.K.; Scott, M.; Foster, D.; Groth, D.F.; DeArmond, S.J.; Prusiner, S.B. Spontaneous neurodegeneration in transgenic mice with mutant prion protein. Science 1990, 250, 1587-1590. [CrossRef]

78. Hsiao, K.K.; Groth, D.; Scott, M.; Yang, S.L.; Serban, H.; Rapp, D.; Foster, D.; Torchia, M.; Dearmond, S.J.; Prusiner, S.B. Serial transmission in rodents of neurodegeneration from transgenic mice expressing mutant prion protein. Proc. Natl. Acad. Sci. USA 1994, 91, 9126-9130. [CrossRef]

79. Yang, W.; Cook, J.; Rassbach, B.; Lemus, A.; DeArmond, S.J.; Mastrianni, J.A. A New Transgenic Mouse Model of Gerstmann-Sträussler-Scheinker Syndrome Caused by the A117V Mutation of PRNP. J. Neurosci. 2009, 29, 10072-10080. [CrossRef]

80. Fischer, M.; Rulicke, T.; Raeber, A.; Sailer, A.; Moser, M.; Oesch, B.; Brandner, S.; Aguzzi, A.; Weissmann, C. Prion protein $(\mathrm{PrP})$ with amino-proximal deletions restoring susceptibility of PrP knockout mice to scrapie. EMBO J. 1996, 15, 1255-1264. [CrossRef]

81. Flechsig, E.; Shmerling, D.; Hegyi, I.; Raeber, A.J.; Fischer, M.; Cozzio, A.; von Mering, C.; Aguzzi, A.; Weissmann, C. Prion protein devoid of the octapeptide repeat region restores susceptibility to scrapie in $\operatorname{PrP}$ knockout mice. Neuron 2000, 27, 399-408. [CrossRef]

82. Weissmann, C.; Flechsig, E. PrP knock-out and PrP transgenic mice in prion research. Br. Med. Bull. 2003, 66, 43-60. [CrossRef] [PubMed]

83. Pan, K.M.; Baldwin, M.; Nguyen, J.; Gasset, M.; Serban, A.; Groth, D.; Mehlhorn, I.; Huang, Z.; Fletterick, R.J.; Cohen, F.E.; et al. Conversion of $\alpha$-helices into $\beta$-sheets features in the formation of the scrapie prion proteins. Proc. Natl. Acad. Sci. USA 1993, 90, 10962-10966. [CrossRef] [PubMed]

84. Wille, H.; Bian, W.; McDonald, M.; Kendall, A.; Colby, D.W.; Bloch, L.; Ollesch, J.; Borovinskiy, A.L.; Cohen, F.E.; Prusiner, S.B.; et al. Natural and synthetic prion structure from X-ray fiber diffraction. Proc. Natl. Acad. Sci. USA 2009, 106, 16990-16995. [CrossRef] [PubMed]

85. Vazquez-Fernandez, E.; Vos, M.R.; Afanasyev, P.; Cebey, L.; Sevillano, A.M.; Vidal, E.; Rosa, I.; Renault, L.; Ramos, A.; Peters, P.J.; et al. The Structural Architecture of an Infectious Mammalian Prion Using Electron Cryomicroscopy. PLoS Pathog. 2016, 12, e1005835. [CrossRef] [PubMed]

86. Baskakov, I.V.; Caughey, B.; Requena, J.R.; Sevillano, A.M.; Surewicz, W.K.; Wille, H. The prion 2018 round tables (I): The structure of $\operatorname{PrP}^{\mathrm{Sc}}$. Prion 2019, 13, 46-52. [CrossRef] 
87. Spagnolli, G.; Rigoli, M.; Orioli, S.; Sevillano, A.M.; Faccioli, P.; Wille, H.; Biasini, E.; Requena, J.R. Full atomistic model of prion structure and conversion. PLoS Pathog. 2019, 15, e1007864. [CrossRef]

88. Caughey, B.; Raymond, G.J.; Ernst, D.; Race, R.E. N-terminal truncation of the scrapie-associated form of PrP by lysosomal protease(s): Implications regarding the site of conversion of $\operatorname{PrP}$ to the protease-resistant state. J. Virol. 1991, 65, 6597-6603. [CrossRef]

89. Borchelt, D.R.; Taraboulos, A.; Prusiner, S.B. Evidence for synthesis of scrapie prion proteins in the endocytic pathway. J. Biol. Chem. 1992, 267, 16188-16199.

90. Walmsley, A.R.; Zeng, F.; Hooper, N.M. The N-terminal region of the prion protein ectodomain contains a lipid raft targeting determinant. J. Biol. Chem. 2003, 278, 37241-37248. [CrossRef]

91. Yu, S.; Yin, S.; Li, C.; Wong, P.; Chang, B.; Xiao, F.; Kang, S.C.; Yan, H.; Xiao, G.; Tien, P.; et al. Aggregation of prion protein with insertion mutations is proportional to the number of inserts. Biochem. J. 2007, 403, 343-351. [CrossRef] [PubMed]

92. Thakur, A.K.; Srivastava, A.K.; Srinivas, V.; Chary, K.V.; Rao, C.M. Copper alters aggregation behavior of prion protein and induces novel interactions between its $\mathrm{N}$ - and C-terminal regions. J. Biol. Chem. 2011, 286, 38533-38545. [CrossRef] [PubMed]

93. Giachin, G.; Mai, P.T.; Tran, T.H.; Salzano, G.; Benetti, F.; Migliorati, V.; Arcovito, A.; Della Longa, S.; Mancini, G.; D'Angelo, P.; et al. The non-octarepeat copper binding site of the prion protein is a key regulator of prion conversion. Sci. Rep. 2015, 5, 15253. [CrossRef] [PubMed]

94. Hegde, R.S.; Mastrianni, J.A.; Scott, M.R.; DeFea, K.A.; Tremblay, P.; Torchia, M.; DeArmond, S.J.; Prusiner, S.B.; Lingappa, V.R. A transmembrane form of the prion protein in neurodegenerative disease. Science 1998, 279, 827-834. [CrossRef]

95. Hegde, R.S.; Tremblay, P.; Groth, D.; DeArmond, S.J.; Prusiner, S.B.; Lingappa, V.R. Transmissible and genetic prion diseases share a common pathway of neurodegeneration. Nature 1999, 402, 822-826. [CrossRef]

96. Shmerling, D.; Hegyi, I.; Fischer, M.; Blattler, T.; Brandner, S.; Gotz, J.; Rulicke, T.; Flechsig, E.; Cozzio, A.; von Mering, C.; et al. Expression of amino-terminally truncated PrP in the mouse leading to ataxia and specific cerebellar lesions. Cell 1998, 93, 203-214. [CrossRef]

97. Li, A.; Christensen, H.M.; Stewart, L.R.; Roth, K.A.; Chiesa, R.; Harris, D.A. Neonatal lethality in transgenic mice expressing prion protein with a deletion of residues 105-125. EMBO J. 2007, 26, 548-558. [CrossRef]

98. Westergard, L.; Turnbaugh, J.A.; Harris, D.A. A nine amino acid domain is essential for mutant prion protein toxicity. J. Neurosci. 2011, 31, 14005-14017. [CrossRef]

99. Turnbaugh, J.A.; Westergard, L.; Unterberger, U.; Biasini, E.; Harris, D.A. The N-terminal, polybasic region is critical for prion protein neuroprotective activity. PLoS ONE 2011, 6, e25675. [CrossRef]

100. Solomon, I.H.; Khatri, N.; Biasini, E.; Massignan, T.; Huettner, J.E.; Harris, D.A. An N-terminal polybasic domain and cell surface localization are required for mutant prion protein toxicity. J. Biol. Chem. 2011, 286, 14724-14736. [CrossRef] [PubMed]

101. Wu, B.; McDonald, A.J.; Markham, K.; Rich, C.B.; McHugh, K.P.; Tatzelt, J.; Colby, D.W.; Millhauser, G.L.; Harris, D.A. The N-terminus of the prion protein is a toxic effector regulated by the C-terminus. Elife 2017, 6, e23473. [CrossRef]

(C) 2020 by the authors. Licensee MDPI, Basel, Switzerland. This article is an open access article distributed under the terms and conditions of the Creative Commons Attribution (CC BY) license (http://creativecommons.org/licenses/by/4.0/). 